\title{
HUKUM-HUKUM DETERMINISME DALAM FILSAFAT SEJARAH IBNU KHALDUN \\ (Dialektika Antara Sains dan Teologi)
}

\author{
Bisri \\ IAIN Syekh Nur Jati Cirebon
}

\begin{abstract}
Abstrak: Ibnu Khaldun merupakan tokoh besar yang tidak diragukan sumbangan pemikirannya, ketokohanya diakui baik di dunia Islam maupun Barat. Bahkan dalam kajian ilmu sejarah maupun filsafat sejarah, ia termasuk tokoh awal yang membangun fondasi bangunan sejarah dari sejarah yang sebelumnya hanya berupa deskripsi peristiwa-peristiwa, nama-nama penguasa atau silsilah keturunan dan angka-angka tahun, menjadi suatu sistem bangunan keilmuan dan filsafat yang utuh. Dalam pemikiran filsafat sejarahnya, Ibnu khaldun termasuk yang menganut determinisme sejarah. Berbicara tentang hukum-hukum sejarah, determinisme sejarah kerap dimaknai sebagai hukum kausalitas. Ibnu Khaldun memberlakukan hukum kausalitas bukan hanya pada alam saja, tetapi juga berlaku pada manusia. Di sisi lain Ibnu Khaldun sebagai penganut Asy'ariyah dimana paham teologi ini menolak hukum kausalitas atas dasar kekuasaan dan kehendak mutlak Tuhan. Ada semacam pertentangan antara paham keyakinan teologi dan paham determinismenya. Paham teologinya menolak kausalitas, sementara ia menganut determinisme dalam sejarah. Disinilah menariknya bahwa kecerdasan Ibnu Khaldun mampu mendamaikan pertentangan antara sains dan teologi dalam menjelaskan hukum determinisme sejarah ini.
\end{abstract}

Kata kunci: Ibnu Khaldun, Determinisme, Filsafat, Sejarah, Dialektika, Sainss, Teologi.

\section{A. Biografi Ibnu Khaldun}

Dalam bisang ilmu atau filsafat sejarah, literatur Arab dihiasi oleh suatu nama yang sangat cemerlang. Baik dunia Kristen klasik, maupun pertengahan, tidak akan mampu menunjukkan seorangpun yang dapat mendekati kecemerlangannya. Ibnu Khaldun (1322-1406 M), kalau hanya dianggap sebagai ahli sejarah saja, ada juga orang-orang yang melebihinya, sekalipun dari kalangan orang-orang Arab sendiri. Tetapi sebagai ahli teori sejarah tidak ada yang dapat 
menandinginya sepanjang zaman dan seluruh negeri, hingga munculnya Vico, lebih dari tiga ratus tahun kemudian. Plato, Aristoteles dan Augustinus bukanlah tandingannya, dan semua ahli pikir lainnya tidaklah patut meski sekedar untuk disebut bersama-sama dengan namanya. Ia patut dikagumi karena keaslian dan kedalamannya, keluasan dan kekuatan pikirannya. Ia adalah orang yang lain, tersendiri dan unik diantara orang-orang seagamanya dan sezamannya dalam lapangan filsafat sejarah, seperti Dante dalam syair dan Roger Bacon dalam ilmu pengetahuan pasti. Setiap orang yang membaca Al-Muqaddimah tidak boleh tidak akan mengakui bahwa Ibnu Khaldun patut memperoleh kehormatan ini, kehormatan pemberian nama sebagai penggagas ilmu dan filsafat sejarah yang lebih dalam dan luas ketimbang para penulis lainnya sebelum Vico. ${ }^{1}$

Nama lengkap Ibnu Khaldun adalah Abd al-rahman Abu Zaid Waliudin Ibn Khaldun. Namanya sendiri adalah Abd al-Rahman. Nama keluarganya adalah Abu Zaid. Sedang gelarnya adalah Waliuddin. Dan ia terkenal dengan Ibnu Khaldun. Keluarga Ibnu Khaldun berasal dari Hadramaut, Yaman. Garis keturunannya keatas lagi adalah Wa'il bin Hajar, seorang sahabat Nabi yang terkenal. $^{2}$

Seiring dengan penaklukan dan penyebaran Islam ke Barat, Ibnu Khaldun bersama-sama dengan pasukan Islam memasuki Andalusia dan menetap di Carmona. Akan tetapi dengan tidak diketahui sebab yang pasti, kemudian Ibnu Khaldun dan keluarganya pindah ke Sevilla, maka Ibnu Khaldun akhirnya hijrah kembali ke Tunisia. Di negeri kelahirannya inilah ia kemudian berkonsentrasi untuk menemukan jati dirinya sebagai pemikir dan penulis, walaupun ketika ia kembali ke negerinya itu, keadaan negeri itu sedang mengalami kemandegan pemikiran, kekacauan politik serta umat Islam saling tidak percaya. Hal itu karena daulah Islamiyah sudah jatuh, sehingga masing-masing wilayah, termasuk Afrika Utara-Tunisia telah melepaskan diri dari pemerintahan pusat di Baghdad. ${ }^{3}$

\footnotetext{
1 Zainab Al-Khudairi, Filsafat Sejarah Ibnu Khaldun (Bandung: Penerbit Pustaka, 1995), 7.

${ }^{2}$ Ibid.,8.

${ }^{3}$ Misri A. Muchsin, Filsafat Sejarah dalam Islam: Ibnu Khaldun, Malik bin Nabi, Fålur Rahman, Murtadha Muthahhari, Abd. Hamid Shiddiqi, Ali Syariati (Jogjakarta: Ar-Ruz Press, 2002), 74.
} 
Pada Oktober 1382 M, Ibnu Khaldun meninggalkan Tunisia menuju ke Alexandria. Masih di tahun itu juga, ia tiba di Kairo Mesir seiring perjalanannya untuk berhaji, yang pada waktu itu kesultanannya dipegang oleh $\mathrm{Abu} \mathrm{Sa}$ 'id Bargug dari keturunan dan kesultanan Mamluk. Ia tiba di Mesir dalam usianya 22 tahun. Mesir yang merupakan pusat ilmu pengetahuan Islam, di mana muslim Timur dan Barat mengenyam ilmu. Oleh karena kecerdasan dan keluasan ilmunya, ia menjadi pengajar di sana, terutama di masjid al-Azhar. Yang jelas, tidak berapa lama ia berada di kota ini, ia sudah terkenal dalam masyarakat, bahwa ilmunya sangatlah luas. Akan tetapi, tidak berapa lama kemudian ia berpindah ke Damaskus, untuk mengabdi di sana. ${ }^{4}$

Ibnu Khaldun dengan karya-karya monumentalnya seperti al-Muqaddimah yang merupakan pendahuluan karya besarnya al-'Ibar, kelihatan memiliki banyak aspek pemikirannya. Zainab al-Khudairi menyebutkan aspek-aspek pemikiran Ibnu Khaldun meliputi filsafat sejarah, ilmu sejarah, ilmu ekonomi, politik dan tasawuf. $^{5}$

Mengapa Ibnu Khaldun menulis al-Muqaddimah? Rupanya ia terpanggil untuk menulis, karen waktu ia hidup, sejarah tidak lebih sekedar mendeskripsikan tentang peristiwa-peristiwa, nama-nama penguasa atau silsilah keturunan dan angka-angka tahun. Hal ini, oleh Ibnu Khaldun dianggap tidak mewakili wawasan disiplin ilmu sejarah. Bertolak dari permasalahan itulah, ia ingin berbuat lebih dari apa yang sudah dilakukan ilmuan saat itu. Ia melakukan pengkajian sejarah tidak terbatas hanya pada persoalan deskripsi, tetapi leih dari itu, untuk menemukan hukum-hukum umum sejarah, sehingga dengan demikian seorang sejarawan dapat bebas dari khurafat, kekacauan dan kekeliruan dalam menulis sejarah. ${ }^{6}$

\section{B. Hukum Determinisme Dalam Filsafat Sejarah Ibnu Khaldun}

Pertama-tama barangkali perlu dijelaskan pengertian tentang determinisme, dengan tujuan agar mempermudah memahami tentang kausalitas. Determinisme adalah keyakinan bahwa segala sesuatu terjadi karena suatu kausa

${ }^{4}$ Ibid.

${ }^{5}$ Ibid., 75 .

${ }^{6}$ Ibid. 
atau berbagai kausa, dan semuanya itu tidak mungkin terjadi dalam bentuk yang berbeda, kecuali apabila terjadi perbedaan di dalam kausa-kausanya. ${ }^{7}$

\section{Hukum Kausalitas}

Menurut Ibnu Khaldun hukum kausalitas adalah salah satu dari tiga hukum determinisme sajarah. Dua hukum lainnya adalah hukum peniruan dan hukum perbedaan. Hukum kausalitas ini diterapkan pada sejarah oleh Montesquieu. Montesquieu menolak asumsi bahwa "Ketentuan yang buta telah menghasilkan segala bekas-bekas yang kita lihat dalam alam". Ia berpendapat bahwa perilaku orang selalu mengikuti hukum-hukum tertentu. Setelah Montesquieu para filosof tidak jemu-jemunya membahas berbagai kausa peristiwa historis dan hukumhukum kendalinya. ${ }^{8}$

Kata Ibnu Khaldun: "Ketahuilah! Kiranya Allah menunjukkan kami dan anda ke jalan yang benar! Sesungguhnya kita melihat alam ini, dengan segala mahluk yang ada di dalamnya, dalam keadaan teratur, kukuh, dan terjalin antara sebab dan akibatnya. Kalimat tersebut menunjukkan secara gamblang pandangan Ibnu Khaldun yang meyakini adanya hubungan kausalitas antara kenyataankenyataan dan fenomena-fenomena. Seperti diketahui hukum kausalitas dikenakan pada ilmu-ilmu kealaman, namun dengan kejeniusannya Ibnu Khaldun menerapkannya pada sejarah. Hanya Herodotus sajalah satu-satunya pemikir sebelum Ibnu Khaldun, yang memahami pentingnya penerapan hukum ini pada perilaku manusia, namun penerapanya secara jelas pertama-tama dilakukan Ibnu Khaldun. ${ }^{9}$

Ibrahim Madkour dalam makalahnya "Ibnu Khaldun al-failasuf” yang disampaikan pada simposium tentang Ibnu Khaldun yang diadakan oleh Pusat Penelitian dan Kriminal Nasional mesir, mengatakan bahwa Ibnu Khaldun berpegang pada dua prinsip yang menjadi landasan filsafat sejarah dan sosiologinya, yaitu prinsip kausalitas dan prinsip perkembangan. "kebalikan dari al-Ghazali (yang Asy’ari dan cenderung Jabari), Ibnu Khaldun berpendapat bahwa antara satu peristiwa dengan peristiwa lainnya dijalin oleh sebagian hubungan

\footnotetext{
7 Zainab Al-Khudairi, Filsafat Sejarah Ibnu Khaldun., 108.

8 Ibid., 109.

${ }^{9}$ Ibid., 109-10
} 
sebab dan akibat, dan kausalitas tidak hanya terbatas kepada bisang kealaman saja tapi juga terjadi pada alam manusia. Jadi, fenomena-fenomena masyarakat manusia juga tunduk pada hukum-hukum yang tetap, masa kininya dapat menjadi penopang dalam menginterpretasikan masa lalunya. ${ }^{10}$

Sementara Abd al-Raziq al-Makki, dalam karyanya al-Fikr al-Falsafi 'Inda Ibn Khaldun, berpendapat bahwa Ibnu Khaldun dalam teorinya tentang kausalitas terpengaruh oleh para tokoh aliran Asy'ariyah, khususnya al-Ghazali, sehingga pandangan Ibnu Khaldun dalam masalah ini bertentangan dengan Aristotelian tentang hukum kausalitas. Uraian Abd al-Raziq al-Makki mengenai hal ini: "Oleh karena itu konsepsi Ibnu Khaldun tentang kausalitas bertentangan dengan konsepsi Aristoteles dan seiring dengan pandangan kaum muslimin, termasuk sikap para pemikir aliran Asy'ariyah terutama sekali al-Ghazali.” Tetapi dalam uraian selanjutnya Abd al-Raziq al-Makki menarik kembali pendapatnya itu dan menyatakan bahwa konsepsi Ibnu Khaldun tentang kausalitas adalah konsepsi Aristotelian. ${ }^{11}$

\section{Hukum Peniruan}

Menurut Ibnu Khaldun, ada dua hukum dalam masyarakat yang selalu bertentangan yang dapat disebut hukum peniruan dan perbedaan. Kata Ibnu Khaldun mngenai hal ini: "Berita-berita, bilamana didasarkan pada penuturan dan tidak dikuatkan oleh pokok-pokok kebiasaan, prinsip-prinsip politik, watak kebudayaan, kondisi-kondisi masyarakat manusia, dan berita-berita yang dialami dan masa kini tidak diperbandingkan dengan berita-berita masa lalu, maka beritaberita tersebut kadang-kadang tidak dapat dipercaya dan membuat kaki tergelincir.",12

Dengan demikian menurut Ibnu Khaldun dari sebagian semua aspek masyarakat manusia adalah sama. Kesamaan ini ditunjukkan Ibnu Khaldun pada kesatuan pikiran manusia, yaitu kesatuan seperti halnya telah diuraikan para filosof metafisika Yunani dan Arab. Jadi tidaklah ada perbedaan diantara jiwa

\footnotetext{
${ }^{10}$ Ibid., 110

${ }^{11}$ Ibid.

12 Ibid., 113.
} 
manusia. Sedang apabila terjadi perbedaan maka hal ini kadang-kadang terjadi karena keistimewaan yang dianugerahkan Allah kepada para Nabi dan Wali. ${ }^{13}$

Ada sebab lain lagi yang menurut Ibnu Khaldun menyebabkan terjadinya kesamaan sosial, yaitu peniruan. Hal ini diuraikan Ibnu Khladun dalam sebuah pasal dengan judul "Kelompok yang kalah selalu berusaha untuk meniru kelompok yang menang dalam pakaian, tanda-rtanda kebesaran, aqidah, dan adat kebiasaan yang lain-lainnya. Dari teks-teks pasal tersebut dapat disimpulkan sebagai berikut: ${ }^{14}$

Pertama: Masyarakat meniru para pemegang kekuasaan

Kedua: Para pemegang kekuasaan tersebut meniru para pemegang kekuasaan sebelum mereka.

Ketiga: Para pemegang kekuasaan yang kalah meniru para pemegang kekuasaan yang baru.

Peniruan, menurut Ibnu Khaldun, merupakan suatu hukum yang umum. Peniruan ini mendorong gerak perkembangan ke depan, sebab kadang-kadang peniruan merupakan peniruan terhadap hal yang lebih baik. Peniru sendiri selalu melengkapi apa yang ditirunya dengan apa yang ia miliki. Sehingga dengan ini menciptakan sesuatu yang baru. Hukum peniruan menurut Ibnu Khaldun ini mengingatkan kita pada hukum imitasi menurut Trade, pemikir Prancis, seperti yang ia uraikan dalam karyanya Les lois de l'imitation. ${ }^{15}$

\section{Hukum Perbedaan}

Hukum perbedaan juga merupakan salah satu hukum determinisme sejarah menurut Ibnu Khaldun. Hukum ini bersama-sama dengan hukum kausalitas dan hukum peniruan merupakan tiga landasan yang menjadi dasar determinisme Ibnu Khaldun.

Masyarakat-masyarakat, menurut Ibnu Khaldun, tidaklah sama secara mutlak, tapi diantara masyarakat-masyarakat itu terdapat perbedaan-perbedaan yang harus diketahui para sejarahwan. Kata Ibnu Khaldun mengenai hal ini: “ kebiasaan-kebiasaan setiap generasi mengikuti adat kebiasaan orang-orang yang

13 Ibid., 114.

14 Ibid.

15 Ibid. 
memerintah mereka, seperti halnya peribahasa berkata: "Rakyat mengikuti agama rajanya". Suatu dinasti akan banyak mengambil kebiasaan dinasti-dinasti yang sebelunya, dengan tidak melupakan adat kebiasaan sendiri, hingga demikian rangkaian adat lembaganya akan berbeda dengan adat lembaga generasi sebelumnya. Bilamana dinasti yang memerintahitu kemudian diganti oleh dinasti yang lain, yang tentu saja dinasti penggantinya itu akan mencampur adat kebiasaannya sendiri dengan adat kebiasaan yang ada, maka terjadilah corak baru dalam adat kebiasaan, yang tentu saja akan berlainan dengan corak yang pertama dan lebih jauh lagi dengan corak yang kedua. Perubahan sedikit demi sedikit yang menuju kearah perbedaan yang semakin besar ini akan terus berjalan hingga sampai kepada perbedaan total. ${ }^{16}$

\section{Dialektika Sains dan Teologi dalam Filsafat Sejarah Ibnu Khaldun}

Sebagai penganut teologi Asy'ariyah, Ibnu Khaldun banyak dipengaruhi oleh pemikiran al-Ghazali. Paham Asy'ariyah yang cenderung Jabariyah terkait dengan paham kebebasan dan kehendak mutlak Tuhan, diidentikkan sebagai berlawanan dengan paham rasional Mu'tazilah dengan semboyan free will-nya. Mu'tazilah menolak keyakinan tentang taqdir, Tuhan menentukan taqdir-Nya kepada manusia melalui sunnatullah yang telah diciptakannya. Sunnatullah inilah yang dalam bahasa sains disebut sebagai kausalitas. Keberanian Ibnu Khaldun dengan teori determinismenya terhadap sejarah dan bahkan (determinisme itu juga) berlaku bagi manusia, seolah menimbulkan pertentangan antara keyakinan teologinya dan pemahaman hukum sejarahnya. Determinisme memuat hukum kausalitas, bahwa ada keteraturan alam yang menjadi sebab dari musabab peristiwa-peristiwa historis. Lalu dimanakah posisi kehendak mutlak Tuhan dalam hal ini. Ibnu Khaldun mencoba mendamaikan dua pertentangan ini dalam konsistensinya sebagi penganut Asy'ariyah dan sebagai seorang ilmuwan sekaligus filosof sejarah.

\section{Determinis dan Probabilistik Dalam Kausalitas}

Berbicara tentang determinisme dalam sains, bahwa paham ini dikembangkan oleh William Hamilton (1788-1856) dari doktrin Thomas Hobbes

${ }^{16}$ Ibid., 115. 
(1588-1679) yang menyimpulkan bahwa pengetahuan adalah bersifat empiris yang dicerminkan oleh zat dan gerak yang universal. Aliran filsafat ini merupakan lawan dari paham fatalisme yang berpendapat bahwa segala kejadian ditentukan oleh nasib yang yang telah ditetapkan lebih dahulu. Demikian juga paham determinisme ini bertentangan dengan penganut pilihan bebas yang menyatakan bahwa manusia mempunyai kebebasan dalam menentukan pilihannya tidak terikat kepada hukum alam yang tidak memberikan alternatif. ${ }^{17}$

Jujun S. Suriasumantri menggambarkan bagaimana determinisme sainss sebagai sebuah asumsi. Ia menjelaskannya dalam bentuk sebuah kisah sebagai berikut: ${ }^{18}$

Pada zaman wild west, seorang jago tembak yang ternama, ditantang oleh seorang petani yang mabuk. Petani ini seorang biasa, dan dipastikan bukanlah tipe seorang janggo yang mempunyai keahlian menembak bahkan dapat menembak sasarannya dengan mata tertutup.

Seorang bandar taruhan melihat kesempatan emas, ia berfikir bahwa ini pertama kalinya seorang jago tembak tersohor yang disegani, ditantang adu tembak oleh seorang petani biasa. Ia ingin membuat taruhan judi, dan tentu saja untuk hal itu ia tidak ingin kalah/rugi walupun hampir pasti bahwa sang janggo akan memenangkan duelnya. Sang bandar pun berkonsultasi kepada seorang konsultan tentang antisipasi peluang terburuk yang mungkin saja sang janggo bisa kalah.

"Lantas apa saja yang mungkin tidak beres?" Tanya sang bandar. "Konsultan menjawab, ya, bermacam-macam, umpamanya katakan sajalah bahwa pistol si Janggo itu punya kehendak sendiri (free will), kan berabe.?” Maksudnya? (tanya sang bandar). Ya mungkin saja pistol itu tidak mau menembak orang tak berdosa, apalagi seorang nonprofesional yang belum diakui kemampuannya.

\footnotetext{
${ }^{17}$ Jujun S Suriasumantri, Filsafat Ilmu: Sebuah pengantar Populer (Jakarta: Pustaka Sinar Harapan Press, 2005), 75.

${ }^{18}$ Ibid., $72-73$.
} 
"Ah, tidak mungkin! Jawab sang bandar. Mana ada pistol punya pilihan bebas. Sekiranya pistol ditembakkan dan tepat pada sasaran maka secara deterministik sasaran itu akan kena."

“Baiklah, kata konsultan, bagaimana kalau pistolnya macet?" macet bagaimana?' (kata sang bandar). Ya, macet, klik! Jawab konsultan itu. Dari data yang dapat dikumpulkan ternyata bahwa dari 100 peluru yang ditembakkan sebuah pistol maka satu diantaranya adalah macet. Artinya, secara probabilistik, meskipun peluangnya 1 dalam 100, mungkin saja pistol jago kita itu macet, yang menyebabkan dia tersambar "chance" (kebetulan) berupa nasib."

Bandar taruhan itu kemudian merenung, ia seperti kebingungan dan sedang berfikir serius. Mereka menduga-duga apakah gejala dalam alam ini tunduk kepada determinisme, yakni hukum alam yang bersifat universal, ataukah hukum semacam itu tidak terdapat sebab setiap gejala merupakan akibat pilihan bebas, ataukah keumuman memang ada namun berupa peluang, sekedar tangkapan probabilistik? Tiga persoalan yang menjadi rumit tersebut adalah berkaitan dengan kemungkinan determinisme, pilihan bebas dan ataukah sekedar probabilistik.

Konsekuensi dari pilihan ini adalah jelas, sebab sekiranya kita memilih hukum kejadian yang berlaku bagi seluruh manusia, maka kita harus bertolak dari paham determinisme. Sekiranya kita memilih hukum kejadian yang bersifat khas bagi tiap individu manusia (bahwa manusia mempunyai kebebasan dalam menentukan pilihan) maka kita berpaling kepada paham pilihan bebas. Sedangkan posisi tengah yang terletak diantara keduanya mengantarkan kita kepada paham yang bersifat probabilistik. ${ }^{19}$

\section{Aspek Agama dan Teologis dalam Gerak Sejarah}

Sejauh manakah dampak agama atas kehidupan sosial dan perkembangannya? Kata Ibnu Khaldun tentang hal ini: "Dengan memandang bahwa kedudukan raja timbul dari keharusan hidup bergaul bagi manusia dan didasarkan kepada penaklukkan dan paksaan..oleh karena itu menjadi suatu keharusan untuk menetapkan suatu hukum-hukum politik yang dapat diterima dan

\footnotetext{
${ }^{19}$ Ibid.,75-76.
} 
diakui rakyat. Apabila hukum itu dibuat oleh pata terkemuka, bijaksana, dan orang-orang cerdik pandai dari kalangan bangsa itu maka pemerintahan itu didasarkan kepada akal. Dan apabila hukum-hukum itu adalah hukum-hukum yang ditentukan Allah dengan perantara seorang pembuat hukum agama (yakni Rasul) maka pemerintahan itu disebut berdasarkan agama. Dan pemerintahan yang demikian itu berguna sekali, baik untuk hidup di dunia ini maupun untuk hidup di akhirat. ${ }^{20}$

Menurut Ibnu Khaldun, kehidupan sosial mungkin saja dapat berlangsung tanpa agama, dan politik dapat tegak tanpa aturan agama. Namun agamaagamalah yang mendorong perkembangan ke depan dan menjadikan kehidupan sosial lebih utama. Ibnu Khaldun dalam sebuah pasal yang berjudul "Agama memperkokoh kekuatan 'ashabiah yang dipupuk negara" berkata antara lain: "Sebabnya ialah seperti yang dijelaskan di awal, semangat agama dapat meredakan pertentangan dan iri hati yang dirasakan oleh salah satu anggota dari golongan itu terhadap anggota lainnya dan menuntut mefreka ke arah kebenaran. Sehingga apabila perhatian mereka sama dan telah berpusat pada kebenaran maka akan menjadi kekuatan yang tidak bisa menghalangi mereka. ${ }^{21}$

Selain itu, cara keberagamaan seseorang baik cara pandang, maupun keyakinannya dipengaruhi oleh corak teologinya. Abd al-Raziq al-Makki, dalam karyanya al-Fikr al-Falsafi 'Inda Ibn Khaldun, berpendapat bahwa Ibnu Khaldun adalah penganut teologi Asy'ariyah, yang banyak dipengaruhi pemikiran alGhazali. Teologi Asy'ariyah dengan teori kasab nya menurut Harun Nasution diidentikkan dengan teologi Jabariyah. Dimana Tuhan memiliki kekuasaan dan kehendak mutlak.

Ciri-ciri teologi kehendak mutlak Tuhan (jabariyah) itu adalah : ${ }^{22}$

a. Kedudukan akal yang rendah.

b. Ketidak bebasan manusia dalam kemauan.

c. Kebebasan berfikir yang diikat dengan banyak dogma.

d. Ketidak percayaan kepada kepada sunnatullah dan kausalitas

${ }^{20}$ Zainab Al-Khudairi, Filsafat Sejarah Ibnu Khaldun., 98.

21 Ibid., 99.

22 Harun Nasution, Islam Rasional (Jakarta: Mizan, 1995), 111-12. 
e. Terikat kepada arti tekstual dari al-Qur'an dan Hadits.

f. Statis dalam sikap dan berfikir.

Dari beberapa ciri yang disebutkan di atas, ciri yang ke empat/bagian (d) ${ }^{23}$ berkaitan betul dengan kepercayaan adanya sunnatullah (kausalitas) atau determinisme. Nampaknya hal ini menjadi penting apabila dilawankan dengan teologi Mu'tazilah yang justru percaya adanya kausalitas/determinisme. Ibnu Khaldun sebagai seorang penganut Asy'ariyah sebagaimana dicirikan oleh Harun Nasution, bahwa ciri-ciri teologi sunnatullah/kausalitas (teologi Mu'tazilah) adalah :

a. Kedudukan akal yang tinggi.

b. Kebebasan manusia dalam kemauan dan perbuatan.

c. Kebebasan berfikir hanya diikat oleh ajaran-ajaran dasar dalam al-Qur'an dan Hadits yang sedikit sekali jumlahnya.

d. Percaya adanya sunnatullah dan kausalitas.

e. Mengambil arti metaforis dari teks wahyu.

f. Dinamika dalam sikap dan berfikir. ${ }^{24}$

Adanya pertentangan ini kemudian menjadi menarik, bahwa seorang Tokoh Ibnu Khaldun disatu sisi ia adalah penganut paham Asy'ariyah namun pada sisi yang lain dia meyakini hukum kausalitas atau determinisme. Sebagaimana kita tahu bahwa determinisme sebagai kausalitas dijadikan dasar hukum dalam ranah sains atau ilmu pengetahuan. Nampaknya ada dua hal dalam pribadi Ibnu Khaldun, yang pertama bahwa kapasitas nya sebagai seorang ilmuan sejarah, bahkan filosof sejarah. Disisi lain sebagai penganut paham Asy'ariyah.

Sebagaimana dikatakan oleh Syahrin Harahap bahwa hampir dapat dipastikan cara setiap orang beragama, bertindak dan berperilaku sangat

\footnotetext{
${ }^{23}$ Para penganut aliran Asy'ariyah menolak hukum kausalitas. Mereka berpendapat bahwa tidak sesuatu pun dalam alam semesta ini yang terjadi sesuai dengan hukum-hukum yang tetap dan tidak pula karena suatu hukum, tetapi semuanya itu terjadi karena kebiasaan yang ditetapkan oleh Allah. Memang sebagian fenomena kadang terjadi berulang-ulang, namun pengulangan ini tidaklah merupakan keharusan. Lihat Zainab al-Khudhairi, Filsafat Sejarab Ibnu Khaldun, 106

${ }^{24}$ Harun Nasution, Islam Rasional. 111-12.
} 
dipengaruhi oleh visi teologi yang dianutnya. ${ }^{25}$ Sehingga mau tidak mau ajaranajaran Asy'ariyah yang dipahami oleh penganutnya itu berimplikasi pada sikap mental dan perilaku penganutnya. Lalu, bagaimana pandangan Ibnu Khaldun sendiri untuk dapat mendamaikan dua persoalan antara keyakinan dan pemikiran yang seolah bertentangan tersebut. Hal ini lah yang menarik bagi penulis, bahwa Ibnu Khaldun mampu sebagai seorang yang cerdik memposisikan ansinya.tara teologi dan sains pada posisi dan por

\section{Determinisme Sejarah Ibnu Khaldun Dialektika antara Sainss dan}

\section{Teologi}

Berkaitan dengan sains dan teologi, akan dibedakan antara hukum sains (kausalitas) dalam pandangan Ibnu Khaldun, dan bagaimana Tuhan berada dibalik sebab dari segala sebab yang ini jelas berkaitan dengan teologinya.

\section{a. Hukum Sains dan Determinisme yang Terbatas}

Menurut Ibnu Khaldun akal manusia tidak mampu memahami segala sebab. Jadi sampai sejauh yang ada akal manusia terbatas. Menurut Ibnu Khaldun dalam uraiannya tentang sebab: "Manusia tidak mampu mengetahui dasar-dasar dan tujuannya. Pada umumnya ia hanya menguasai satu ilmu tentang sebab-sebab yang merupakan watak suatu fenomena". "Jadi pada umumnya dampak sebabsebab ini dari musabab-musababnya tidaklah diketahui. Ini karena sebab-sebab tersebut didasarkan pada kebiasaan (adat) karena adanya bukti yang didasarkan pada kenyataannya. Sedangkan hakekat dampak tersebut dan bagaimana proses terjadinya tidaklah diketahui. ${ }^{26}$

Sesungguhnya Ibnu Khaldun terhadap hukum kausalitas tidaklah berarti bahwa manusia menjadi diliputi semua sebab. Manurut Ibnu Khaldun, hal itu adalah mustahil dan lebih jauh lagi, setiap upaya untuk mencapai musabab dari segala sebab juga merupakan hal yang mustahil dan malah diperingatkannya untuk tidak dilakukan, karena pendakian sebab-sebab menuju sebab yang pertama

${ }^{25}$ Syahrin Harahap, Islam: Konsep dan Implementasi Pemberdayaan (yogyakarta: Tiara Wacana,1999), 29-30.

${ }^{26}$ Zainab Al-Khudairi, Filsafat Sejarah Ibnu Khaldun., 106. 
akan membuat sebab-sebab itu semakin meluas dimana akal tidak dapat memahaminya. ${ }^{27}$

Barangkali dalam kajian filsafat ilmu bahwa dalam sains sendiri, kausalitas bukanlah sebuah ketentuan yang mutlak. Sains kaitannya dengan kausalitas/deterministik lebih bicara pada peluang atau probabilistik. Dari sisi ini sebenarnya ada peluang yang memungkinkan terjadinya sesuatu yang itu tidak melalui mekanisme hukum kausalitas. ${ }^{28}$

Dengan demikian dapat disimpulkan bahwa determinisme Ibnu Khaldun pertama, bahwa kausalitas dalam hal ini dipahami sebagai sebab-sebab yang didasarkan pada kebiasaan (adat) karena adanya bukti yang didasarkan pada kenyataannya. Artinya tidak lebih jauh kepada pendakian sebab-sebab menuju sebab yang pertama karena akal tidak dapat memahaminya. Kedua, kaitanya dengan sebab manusia mempunyai keterbatasan dalam memahami dasar-dasar, tujuan dan hakekatnya.

Ibnu Khaldun menceritakan tentang tentara Islam dalam perang Yarmuk dan Qadisiah dimana jumlah tentara muslim berjumlah kurang dari 30.000 orang, padahal tentara Persia di Qadisiah berjumlah 120.000 orang, sedang tentara Heraclius, menurut al-Waqidi, terdiri dari 400.000 orang. Sungguhpun demikian kedua lawan itu tidak sanggup berhadapan dengan tentara Arab dan kedua-duanya dikalahkan. $^{29}$

Dengan demikian menurut Ibnu Khaldun kemenangan yang luar biasa itu, berlawanan dengan semua hukum peperangan yang riil, artinya, inilah salah satu peristiwa yang terjadi diluar mekanisme hukum kausalitas, tetapi terjadi karena agama.

\section{b. Teologi Kehendak Mutlak Tuhan}

Dalam mengukuhkan tauhid, Ibnu Khaldun menggunakan bukti rasional, yaitu bahwa Allah adalah kausa yang mempengaruhi dan tidak ada kausa lain selain-Nya. Ibnu Khaldun dalam Muqaddimahnya: "Tauhid adalah ketidak mampuan untuk memahami sebab-sebab, proses-proses terjadinya, dampaknya,

\footnotetext{
${ }^{27}$ Ibid., 110-11.

${ }^{28}$ Jujun S Suriasumantri, Filsafat Ilmu. 75-6.

${ }_{29}$ Zainab al-Khudhairi, Filsafat Sejarah Ibnu Khaldun., 97.
} 
dan penisbatan hal tersebut pada Khaliknya. Sebab tiada pelaku selain-Nya dan segala sebab bersumber dari-Nya. Dan kembali pada kekuasaanNya. ${ }^{30}$ Mengembalikan segala sebab dan sumber kepada Tuhan, sama dengan istilah dalam teologi bahwa Tuhanlah yang mengatur dan menentikan segalanya, dalam hal ini Tuhan punya kekuasaan dan kehendak mutlak. ${ }^{31}$

Dari peristiwa alam yang terjadi secara teratur dalam koridor hukum alam(kausalitas) tersebut menurut Ibnu Khaldun bukanlah suatu keharusan. Fenomena alam tersebut merupakan gejala yang paling sederhana yang sejauh dapat diamati dan terjadi secara berulang untuk bisa dicari bukti secara nyata penyebabnya. Namun dari semua itu menurutnya, Allah pada akhirnya adalah sebab yang pertama yang menjadi tempat kembali segala sebab. Dalam mengunghkapkan hubungan satu fenomena dengan fenomena lainnya kadangkadang ia mempergunakan kata "adat". ${ }^{32}$ namun demikian Ibnu Khaldun tetap memegangi hukum kausalitas dalam kedudukanya sebagai hukum esensial terpenting bagi tegaknya suatu ilmu dan hukum determinisme sejarah yang terpenting.

\footnotetext{
30 Ibid., 107.

31 Bandingkan dengan teologi Mu'tazilah bahwa kekuasaan dan kehendak Tuhan itu terbatas. Tuhan telah memberikan kebebasan kepada manusia dengan diberikan daya dan kemampuan akalnya. Paham Mu'tazilah ini tidak mempercayai adanya Taqdir, bagi mereka Taqdir Tuhan itu adalah melalui sunnatullah/hukum alam yang telah diciptakan-Nya.

32Zainab al-Khudhairi, Filsafat., 106.
} 


\section{DAFTAR PUSTAKA}

Al-Khudairi, Zainab. 1995. Filsafat Sejarah Ibnu Khaldun. Bandung: Penerbit Pustaka.

Harahap, Syahrin. 1999. Islam: Konsep dan Implementasi Pemberdayaan. yogyakarta: Tiara Wacana.

Muchsin, Misri A. 2002, Filsafat Sejarah dalam Islam: Ibnu Khaldun, Malik bin Nabi, Fazlur Rahman, Murtadha Muthahhari, Abd. Hamid Shiddiqi, Ali Syariati. Jogjakarta: Ar-Ruz Press.

Nasution, Harun. 1995, Islam Rasional. Jakarta: Mizan.

Suriasumantri, Jujun S. 2005. Filsafat Ilmu: Sebuah pengantar Populer (Jakarta: Pustaka Sinar Harapan Press. 